\title{
DNA-Profiling and information technology
}

\author{
Citation for published version (APA):
}

Lavranos, N. (1994). DNA-Profiling and information technology: A new weapon for crime detection and prevention? European Journal of Crime, Criminal Law and Criminal Justice, 2(4), 359-378. https://doi.org/10.1163/157181794X00232

Document status and date:

Published: 01/01/1994

DOI:

10.1163/157181794X00232

Document Version:

Accepted author manuscript (Peer reviewed / editorial board version)

\section{Please check the document version of this publication:}

- A submitted manuscript is the version of the article upon submission and before peer-review. There can be important differences between the submitted version and the official published version of record.

People interested in the research are advised to contact the author for the final version of the publication, or visit the DOI to the publisher's website.

- The final author version and the galley proof are versions of the publication after peer review.

- The final published version features the final layout of the paper including the volume, issue and page numbers.

Link to publication

\footnotetext{
General rights rights.

- You may freely distribute the URL identifying the publication in the public portal. please follow below link for the End User Agreement:

www.umlib.nl/taverne-license

Take down policy

If you believe that this document breaches copyright please contact us at:

repository@maastrichtuniversity.nl

providing details and we will investigate your claim.
}

Copyright and moral rights for the publications made accessible in the public portal are retained by the authors and/or other copyright owners and it is a condition of accessing publications that users recognise and abide by the legal requirements associated with these

- Users may download and print one copy of any publication from the public portal for the purpose of private study or research.

- You may not further distribute the material or use it for any profit-making activity or commercial gain

If the publication is distributed under the terms of Article $25 \mathrm{fa}$ of the Dutch Copyright Act, indicated by the "Taverne" license above, 


\section{Introduction}

For many decades now criminal investigators of (violent) crimes collect evidence of the suspect, at the scene of crime and/or from the victim itself to "individualise" the found evidence. ${ }^{1}$ Most common is the detection of fingerprints, blood and semen traces with the aim to compare them with existing files and with the ones of the suspect to attribute the result to the true offender, thus solving a crime case. The high convincing power of such evidence is - specially regarding fingerprints due to the fact, that every human being has its own unique fingerprint. Although the techniques for fingerprints have been constantly improved only the invention and subsequent in troduction of DNA-profiling (also called DNA-fingerprinting) in criminal investigations has indeed marked a "revolution" in the area of serology. ${ }^{2}$ At the same time information technology has been used by law enforcement agencies for quite a while now. In addition, DNA-profiling becomes more widespread and thus is used in an increasing number of cases. Hence, a powerful doubleimpact is achieved by the extremely fast progress and possibilities in information technology as well as dataprocessing ${ }^{3}$ and the increased use of DNA-profiling in the daily work of police and prosecution authorities. In this article the impact of DNA-profiling in alliance with information technology in the field of crime prevention and detection is examined. Special attention is given to the dangerous potentials which DNA-profiling and information technology could cause, particularly regarding privacy rights.

Since DNA-profiling involves complicated micro-biological issues, it is imperative to have an understanding of what DNA is and how the DNA-profiling is conducted. Therefore, in the first part I will very briefly explain what DNA is and how the DNA-profiling is performed.

In the second part, the issue is discussed whether the DNAprofiling can be a new wonder weapon for crime prevention and detection in general. For this purpose I shall outline the legal status of DNA-profiling in various countries. Thereafter, the impact that DNA-profiling can and will have in conjunction with information technology on crime prevention and privacy rights will be analyzed.

At the end the article will give an outlook to future developments and some critical remarks about DNA-profiling in general.

\section{The technique of DNA-profiling}

\section{THE DNA}

In 1944 Oswald Avery made the breakthrough discovery that DNA is the basic genetic material. A few years later, in 1953, James Watson and Francis Crick discovered the molecular structure of the DNA. Yet, only in 1976 the geneticist Alec Jeffreys used for the first time the DNA-profiling in a criminal case involving two raped and strangled girls in England. ${ }^{4}$ Since then DNA-profiling spread to the United States and later to continental Europe.

Life on earth is based on cells; almost every cell has a nucleus; in the nucleus of every cell is DNA (dexyribonucleic acid) and although the nucleus is very small it contains a dazzling amount of information. This information gives the instructions for the formation, structure and function of the entire human body. ${ }^{5}$ The DNA consists of two long strands that form together a double helix. Each of the two strands is composed of a backbone of alternating sugar (dexyribose) and phosphate units. At right angles to this backbone various nitrogen-containing bases (adenine (A), thymine (T), guanine (G) and cytosine (C)) are connecting both strands of the DNA. The specific sequence of these bases determines the genetic instructions. The genetic instructions are contained in the chromosomes and the core of every chromosome consists of DNA. Each of the ${ }^{46}$ chromosomes include a continuous, unbroken filament of duplex DNA which is coiled with other components of the cell. Thus, the precise sequence and the place they occur are the unique feature of the DNA. Furthermore, specific sequences of the bases mark the beginning and the end of the genes. Moreover, the place the chromosomes take (locus, loci) may not always be $100 \%$ identical in every human being. This variation is called 'allele'. Normally, the variations of the alleles are extremely small and negligible, but especially in the regions between the genes a high number of (so called 'hypervariable') alleles are found. These hypervariable loci are so different within a population that it is assumed that every human being has its own unique, very specific hypervariable loci arrangement. This assumption - some geneticists say it's a fact - is the central advantage of which use is being made when a DNA-profiling is done. ${ }^{\circ}$ Therefore, the DNA-profiling is also called DNA-fingerprinting or genetic fingerprint. Furthermore, two important points should be noted. First, the sequence of one of the two strands always resembles the sequence of the other strand, because only certain pairing relations between the two strands are possible: (A) will pair only with (T) and (C) only with (G). This is important in case only one strand is available or usable due to degradation or contamination because the DNA-profiling can still be done. Second, the hypervariable alleles that separate the genes (also called 'minisatellites') which differ in length and are supposed not to contain any genetic information in regard to the individual's personality - belong to the 'non- 
codified' part of the DNA. ${ }^{7}$ This - as we will see later - very important assumption by lawyers and lawmakers (which is constantly stated) is wrong. The 'codified' part of the DNA contains only the programmes for developing the proteins that are practically identical with all human beings - otherwise human beings would not look like human beings but more like elephants. Yet, almost everybody emphasizes this distinction between non- and codified DNAarea. Presumably, to defuse any concerns in regard of possible abuse of the individual genetic data. Nevertheless as I explained above - exactly the so called 'non-codified' hypervariable part contains all the distinctive individual, unique features which makes it possible to identify individuals with such a high probability. That's why DNAprofiling is conducted in the 'non-codified' hypervariable loci area. ${ }^{8}$ This misapprehension will soon not be relevant anymore because several projects have been set-up world-wide with the ambitious aim to decode the complete genetic make-up of mankind until the year $2000,{ }^{9}$ thus making this distinction between non- and codified areas obsolete.

\section{DNA-PROFILING TECHNIQUE}

After describing the basic micro-biological principle of DNA, we now have to understand the technique of DNAprofiling in order to be able to evaluate properly the positive and negative potentials of DNA-profiling.

The DNA-profiling technique can be summarized in a seven-step procedure. First, DNA must be collected from blood, semen, tissue or hair either from the scene of crime, from the suspect or from the victim. The problem often is that the minimum amount to perform a DNA-profiling can not be recovered or the DNA is contaminated or degraded. ${ }^{10}$ Secondly, the DNA must be extracted from the recovered cells. This is done by disrupting the cellular material by using a strong detergent (SDS=sodium dodecyl sulphate). Simultaneously, the cellular proteins are cracked down and digested by using the digestive enzyme (proteinase $\mathrm{K}$ ) in a suspension heated at $50-60 \mathrm{C}$ for several hours. ${ }^{11}$ Thirdly, the DNA fragments have to be separated according to their length. The separation is accomplished by putting a well that contains the DNA fragments in agarose gel which is divided by lanes. Since DNA is negatively charged a voltage is applied and the fragments travel in the gel from the negative pole to the positive pole. Because the DNA fragments differ in size the shorter fragments travel faster than the longer ones, thus creating a distinct pattern. In addition, in one lane DNA fragments are running as 'size markers'. ${ }^{12}$ Fourth, the DNA double helix is broken up in the middle (denatured) in order to obtain the two strands which are transferred on to the surface of a nylon membrane (Southern Transfer). To prepare the next step of 'Hybridization' the DNA probe has to be radioactively labelled by using the radioactive isotope phosphorus-32. The labelling is achieved by using an enzyme which substitutes every occurrence of one of the bases (A), (C), (G), (T) as well as every phosphorus atom of the back-bone of the DNA. ${ }^{13}$ The hybridization is achieved by combining one DNA strand with the labelled DNA strand. As I explained above, both DNA strands are complementary to each other so that the radioactively labelled strand will form a double helix with the other DNA-strand again. ${ }^{14}$ At this stage the radioactively labelled DNA probe is placed between two pieces of X-ray film. After the development, the film shows a pattern that reflects the various DNA fragments in regard to their length and position. Now the precise positions can be measured by an expert. Since with this method the visual clarity is not very good - which can lead to misinterpretations - computers are used more frequently which can measure it much more precisely and objectively.$^{15}$ As a final step, the DNAprofile has to be compared on the one hand with the profiles of the suspect and on the other hand with the use of population genetics in order to make an accurate estimation of probability of how many other individuals could have the same DNA-profile. Only now a match or no match can be declared.

\section{PROBLEMS LINKED WITH DNA-PROFILING}

Although, there is common consensus within the scientific community that DNA-profiling can yield results with a very high probability ${ }^{16}$ the complex procedure of DNA-profiling is not without problems. At every phase of the seven-step procedure just described, mistakes and improper handling of the DNA-probe can produce false results which in some cases could lead to a life sentence or even death-penalty judgement. Therefore, a short summary of the potential errors which can arise is important in order to comprehend also the dangers of DNAprofiling.

A distinction can be drawn between (a) technical errors and (b) population genetics errors which can arise as a matter of false calculation and/or wrong interpretation based on the calculations.

\section{(a) Technical errors}

Firstly, the DNA-probe can be contaminated or degraded. This is specially the case with field samples. The contamination can be caused by bacterial, viral, other non-human DNA or by blood or saliva traces of police officers or laboratory personnel when handling the DNA. The degradation is especially likely when the DNA is in warm, moist conditions. Normally, DNA degrades in a couple of days and vaginal swabs even in a few hours since the vaginal secretions penetrate the DNA of the sperm. An exception are blood and semen stains outside the vagina which dry quickly and can yield results even after a few weeks. Another point is the handling of the recovered 
DNA-probe. The probe has to be put immediately in a deep freezer cooling as low as $-70 \mathrm{C}$ or even lower. ${ }^{18}$ Furthermore, the DNA samples can be mixed up by the police or the laboratory personnel; this actually took place in one case ${ }^{19}$ or the amount of the DNA can be insufficient. ${ }^{20}$ Secondly, a significant "source of error" ${ }^{21}$ is the incomplete digestion of the DNA by the restriction enzymes. The other extreme can be an over-digestion also called 'staractivity'. Thirdly, a 'band shift' can occur, meaning that the DNA fragments which are put in several lanes next to each other can influence each other's mobility, thus causing wrong results of the gel electrophoresis. In connection with the problem of 'band shift', the gel electrophoresis itself may not be conducted properly, i.e. the voltage can be too low or too high or the concentration of the gel can be incorrect. Finally, the expert who determines a match can be biased or put in other words: "[..] people tend to see what they expect to see and it's, of course, true that there are very large financial interests in the success of the tests, and their continued adoption by the courts. The people carrying out the tests have vested institutional interests in prosecutions being successful". ${ }^{22}$ All these points are, of course, by far not the only ones but they show that "[..] the practical problems of actually doing the test should not be underestimated. The process is very labour intensive and needs both meticulous expertise and much experience in reading and interpretation of the bands." ${ }^{23}$ However to be fair, some improvements have been introduced to decrease these factors. ${ }^{24}$

\section{(b) Population genetics errors}

To establish a (no) match the comparison of the DNA sample from the scene of crime or from the victim and the DNA of the suspect is insufficient. The result would only imply that the samples are identical, yet this does not verify the hypothesis that the suspect is the factual offender. To ascertain that, the frequency of such a matching DNA-profile that might occur by chance in the relevant population must be calculated. ${ }^{25}$ Normally, the race of the suspect or defendant determines the type of the population genetics used. DNA databases of the main races African American, Caucasian (European race), Asians and Hispanics exist. Still, many complicated problems in regard of the population genetics arise that I can not describe here. ${ }^{26}$ However, I would like to mention briefly a few points that must be kept in mind. Since, the existing population databases refer only to the main races mentioned above, the question is how safely can these databases be used for other races like AfricanCaribbean or South East Asians. The fact is that the variations can be very high. ${ }^{27}$ Another point is, that these databases are calculated on the assumption of the Hardy-Weinberg equilibrium and linkage equilibrium. These equilibriums assume that marriage in a given population is random and therefore the alleles of a given loci are transmitted randomly as well. The question is, do these equilibriums equally apply to the intermarriage frequency of subcultures and isolated tribes and communities. Such subcultures may have different frequencies of the alleles which are not as randomly as assumed for the main populations. ${ }^{28}$ That would drastically increase the possibility that more individuals could have a matching DNAprofile. Furthermore, statistical errors, the size of the population used for calculation and other mistakes can all add up to wrong probability figures.

\section{DNA-profiling - new wonder weapon for crime prevention and detection?}

In this section I shall examine, the legal basis of DNAprofiling in various countries and how DNA-profiling is and will be used by the police and prosecution authorities. I will draw a distinction between (1) the legal basis of the use of DNA-profiling in criminal cases and (2) the use of DNAprofiling in conjunction with information technology in the field of crime prevention and detection.

\section{LEGAL BASIS OF DNA-PROFILING}

The first question that has to be examined is, whether and under which circumstances the police has the power to obtain body fluids (blood, semen), hair or any other material with which DNA-profiling can be done. Furthermore, the question is whether the existing laws for taking blood or semen samples for ordinary examinations cover sufficiently also the DNA-profiling or whether new laws are necessary.

\subsection{Germany}

The only relevant legal basis in German law which might be applicable in regard to DNA-profiling is to be found in $\S 81$ a StPO (penal procedure code), stating that examinations of the suspect's body are allowed in order to obtain facts which might be of importance for the investigation of the case. Furthermore, the taking of a blood sample is explicitly mentioned, if performed by a doctor. Finally, it is commonly accepted that the suspect has to submit himself/herself passively but needs not to participate actively in the examination(s). ${ }^{29}$ Hence, the extraction of blood is allowed and is also widely used as a standard procedure for determining the alcohol content in the blood as well as the blood group of the suspect. Besides, § 81c StPO allows the extraction of blood samples of "other persons" without consent if it is imperative to find out the truth. The central issue in Germany is, whether or not the DNAprofiling done with a lawfully obtained blood sample is also covered by $\S 81$ a StPO. Especially, the question comes up whether DNA-profiling might be in conflict with basic rights (Grundrechte) guaranteed by the German 
constitution (Grundgesetz). Specifically, the right of privacy and the right of one's own information (Art. 2 (1) in connection with Art. 1 (1) Grundgesetz, German Constitution). The right of one's own information (informationelles Selbsbestimmungsrecht) has been elevated to a further basic right, that becomes evermore important in the light of continuously improving information technology in conjunction with the rising tendency of the state to amass more and more information of its people. ${ }^{30}$ Furthermore, intrusions in this basic right are only allowed if they are necessary, proportional, justified by the public interest and based on a law. Important to know in this context is, that the taking of a blood sample itself has been generally accepted under the relevant basic rights. Obviously, the views in regard of DNA-profiling differ widely. The conservative camp sees no problem at all and argues, that the lawfully extracted blood sample can also be processed for a DNA-profile - making no distinction between standard bloodtests and DNA-profiling. Especially, since in the future less or no intrusion into the body is necessary, because hair or saliva samples can be used, no new laws are needed. ${ }^{31}$ The several decisions by German courts, including the highest (BGH), have taken a similar point of view, ${ }^{32}$ and have accepted the DNA-evidence albeit with the reservation that DNA-evidence could not be the sole evidence on which a judgement can be based on. ${ }^{33}$ The liberal camp on the other hand, is vehemently concerned and demands a new law which clearly describes when and how DNA-profiling is to be used. ${ }^{34}$ Another aspect of concern is the question of storing and processing of DNAinformation: Of whom (victims and/or suspects)? Where? How long? Who has access to the data? ${ }^{35}$ Accordingly, the Datenschutzbeauftragte des Bundes (Independent Commissioner for Data protection) is demanding a new law since DNA-profiling can not be compared with the standard bloodtesting because it involves a new dimension of gathering highly sensitive information. ${ }^{36}$ In the light of the hot debate it is not surprising, that the Ministry of Justice drafted in December 1989 a new to be inserted $\S 81$ e StPO, stating that DNAprofiling can be performed by a doctor without consent of the suspect, if it is necessary to prove that detected traces are actually from that person. The blood sample or samples of other cells have to be destroyed after the criminal prosecution is completed. The DNAprofiling should not be performed in the 'codified' area. Furthermore, the DNA-profiling can be done with blood samples of "other persons" without consent if it is imperative to find out the truth. It is obvious that this proposal leaves many questions unanswered for example: what happens with the information of the destroyed samples? 'Codified' and 'non-codified' area is irrelevant. What means "other persons"? The family and friends of the suspect? The whole city or the whole country? All homosexuals or drugaddicts? What happens with the DNA-information of those "other persons"? Will they be stored? Who has access to them? It is not the place here to go into a deep discussion, ${ }^{37}$ but in my mind this draft raises paramount problems, especially in conjunction with the expanded utilization of high-tech information technology by the police. An important point to note in this context is, that one of the reasons for drafting the proposal was to legalise the illegal, secret setting-up of several police DNA-profiling laboratories by the Bundeskriminalamt (BKA) which proudly announced that the laboratories are ready to start executing DNA-profiling at the end of $1989 .{ }^{38}$

\subsection{England}

According to present English law, a suspect that has not been arrested has to give his consent for a DNA-profiling. Should the sample be obtained by a trick of the police it can be excluded under section 78 of the Police and Criminal Evidence Act $1984 .{ }^{39}$ If the suspect is arrested because of mounting evidence, than sections ${ }^{62}$ (intimate samples) and 63 (nonintimate samples) of the Police and Criminal Evidence Act 1984 become relevant.

Firstly, intimate and non-intimate samples have to be defined.

Section 65 defines an intimate sample as:

"a sample of blood, semen, or any other tissue, fluid, urine, saliva or pubic hair, or a swab taken from a person's body orifice."

a non-intimate sample as:

"(a) a sample of hair other than pubic hair;

(b) a sample taken from a nail or under a nail;

(c) a swab taken from any part of a person's body other than a body orifice;

(d) a footprint or similar impression of any part of a person's body other than a part of his hand."

Obviously, the taking of intimate sample is more intrusive than the taking a non-intimate sample, thus the conditions under which intimate samples can be obtained are more rigid. Accordingly, section 62 requires a written consent of the suspect and the order for the DNA-profiling must be given by a police officer of at least the rank of superintendent and provided that he has reasonable grounds: 
"(a) for suspecting the involvement of the suspect in a serious arrestable offence; and

(b) for believing that the sample will tend to confirm or disapprove his involvement."

Thus, if all the above mentioned conditions are met, the police may proceed with the taking of the sample, only after the suspect has been informed of the order and the grounds on which it was given as well as the offence that he is charged of having committed. In addition, all these matters have to be recorded and samples other than urine or saliva have to be taken by a registered doctor. ${ }^{40}$ However, it should be noted, that no legal advice should be available as well as no prior judicial authorisation is required. ${ }^{41}$ The issue here is what happens if the suspect refuses to give his consent.

Section 62, 10 states that the refusal may be treated as, or capable of amounting to, corroboration of any evidence against the suspect. Although, it should be noted that corroboration is not to be treated as strong as actual evidence and can not be used for solely linking the suspect to the crime. However, the corroboration argument can be a strong means to force suspects into giving their consent. From the point of view of the police section 62 is not a convenient tool, since it dependence on the consent of the suspect and the other strict conditions.

Therefore, we have to turn our attention to the less intrusive and less strict possibility of taking non-intimate samples. Under section 63 written consent is also necessary and in case of refusal it can be treated as corroborative evidence - that is the same situation as under section 62 . However, the police can take a sample by force, if it is ordered by a police officer of the rank of superintendent or higher and if the grounds as stated above for section 62 are fulfilled. The advantage of section 63 is, that the refusal can be overpowered. The disadvantage is that the types of samples that can be obtained under section 63 are presently not very useful for DNA-profiling ${ }^{42}$ - although the improvement of DNA-profiling could allow to use such samples as well. Another issue is the information gained by DNA-profiling. Under section 64 nonintimate and intimate samples have to be destroyed after the suspect is cleared or not prosecuted. But what happens with the records and other data of the DNA-profile? Here section 64 is silent. Thus, it becomes clear that the legal powers for obtaining samples for DNA-profiling are inadequate and need a new legal basis. ${ }^{43}$ Which direction a new law could take is evident in Northern Ireland where the Criminal Justice Act 1988 re-classified mouth swabs as a non-intimate sample, thus enabling DNA-profiling with saliva as it is now possible. ${ }^{44}$ Another issue is the question of admissibility of DNA-profiling as evidence.

In English law the only prerequisite for scientific evidence is, that the evidence meets the traditional requirements of relevancy and helpfulness. ${ }^{45}$ That means it is up to the judge and the jury to decide whether the evidence meets those requirements. Furthermore, the 'doctrine of free proof' demands that evidence which is relevant has to be admitted unless there is a good reason for not admitting it. The doctrine of free proof is based on the assumption that the best way for determining whether and how convincing the evidence is, is to submit it to cross-examination, challenge it with defence evidence and putting up a defence expert in order to contradict the evidence put forward by the prosecution and then leaving it to the jury to decide. ${ }^{46}$ Thus, in England scientific evidence, including DNA-profiles, is weighted as to its proving capabilities and not as an admissibility issue. In several cases the DNA-profiling was admitted and helped declaring convictions, ${ }^{47}$ although in one recent case the DNA-evidence was successfully challenged because of errors in the conducting of DNA-profiling. ${ }^{48}$

\subsection{United States of America}

Since the Frye case of 1923 the criterion for admitting novel scientific evidence is based on the so called Fryestandard which postulates:

"Just when a scientific principle or discovery crosses the line between experimental and demonstrable
stages is difficult to define. Somewhere in this twilight zone the evidential force of the principle must be
recognized, and while courts will go a long way in admitting expert testimony deduced from well-
recognized scientific principle or discovery, the thing from which the deduction is made must be
sufficiently established to have gained general acceptance in the particular field in which it belongs."

Obviously, this definition in rather general terms caused a heated debate. The supporters of the Frye-standard point out to its reliability and uniformity of application. ${ }^{50}$ The critics argue that it is too imprecise. For example: what is meant by 'general acceptance' - all scientists or a majority of them? What exactly must be generally accepted - the underlying theory, the technique or the application? Which exactly is the proper 'particular field' - forensic science in particular or micro-biology in general ${ }^{51}$ All these questions illuminate that the Frye-definition gives rise to an extensive range of different interpretation and application of it. 
In the following section the main different approaches are briefly illustrated. All approaches basically revolve around the question whether DNA-evidence belongs to the pre-trial admissibility stage decided by the judge and excluding the jury, or whether it is a question of weight that is to be decided by the jury alone.

\subsubsection{Strictly interpreted Frye-standard}

One prominent case which illustrates a strict interpretation of the Frye-standard is the United States v. Porter case. In this case the judge restricted the margin of 'general acceptance' by stating, that the DNA-principles as well as the DNA-technology applied by forensic science has to be accepted. Although, the DNA-technique has been applied for several years under clinical circumstances, the application in forensic science has proved to be ambiguous. Furthermore, a distinction between the DNAprofile technique and the use of population genetics was drawn. Accordingly, the judge held that the DNA-technique itself was firmly accepted by the relevant scientists, however the method of the FBI's calculation of the population genetics used is not generally accepted and therefore the DNAevidence can not be admitted. This is particularly so, because the calculated probability and thus the evidential power of DNA-profiling depends on the population genetics. Moreover, it was stated that the general acceptance is a question of admissibility, hence to be decided by the judge, whereas the question whether the DNA-technique was performed properly and how convincing it is in a particular case, is a question of weight, thus has to be decided by the jury. ${ }^{52}$

Another case, People v. Lipscomb, displays also a restricted definition of the Frye-standard - although the judge held the DNA-evidence admissible. The similarity of the Porter and the Lipscomb cases is, that both judges argued that the result reliability and the question of correct conducting of the DNAprofile is not an issue of admissibility but rather one of weight and has therefore to be decided solely by the jury. ${ }^{53}$

\subsubsection{The relevancy approach of the Frye-standard}

This approach claims not to concentrate on the 'general acceptance' requirement but rather argues on the basis of Rule 401, 702 and 403 of the Federal Rules of Evidence.

Rule 401 states that evidence is relevant if it:

"has any tendency to make the existence of any fact that is of consequence to the determination of the action more probable or less probable than would be without the evidence."

In addition, Rule 702 of the Federal Rules of Evidence are considered:

"If scientific, technical or other specialized knowledge will assist the trier [jury] of fact to understand the evidence or to determine a fact in issue, a witness qualified as an expert by knowledge, skill, experience, training or education, may testify thereto in the form of an opinion or otherwise."

Finally, Rule 403 of the Federal Rules of Evidence is taken into account:

"Although relevant evidence may be excluded if its probative value is substantially outweighed by the danger of unfair prejudice, confusion of the issues, or misleading the jury or by considerations of undue delay, waste of time, or needless presentation of cumulative evidence."

Since, the DNA-profiling has such a high presumed convincing power and since it seems difficult to prove that the conditions of exclusion of Rule 403 are fulfilled, DNA-profiling should be easier admissible than under the strict Frye-standard. However, the following case-examples will show that the central issue here is also the scientific reliability of DNA-profiling. In addition, the task of the judge and the jury play an important role here as well. ${ }^{54}$

The first example is the United States v. Jabobetz case in which the DNA-evidence was held admissible, based on the relevancy approach, on the grounds that the DNA-profiling is a sufficiently reliable scientific technique. ${ }^{55}$ Furthermore, the court stated that the DNA-profiling is a significant improvement in forensic science that is understandable to most people. Concerning Rule 403, the court had to focus on the question whether DNA-profiling should be admitted when put forward by the prosecution to prove the identity.

This was resolved by examining the following three questions: Is the DNA-profiling a reliable technique? Was it properly applied in this case? Does its probative value outweigh the danger of unfair prejudice against the defendant? 
The first two questions posed no problems and were answered in the affirmative. The last question concerning the danger of unfair prejudice the court conceded, that the DNA-evidence is sure to influence a jury since it is highly persuasive. But the reliability of the evidence outweighs any potential for unfair prejudice against the defendant. Especially, because the defendant could effectively contest any "aura of infallibility" by means of hefty crossexamination, opposing expert witness and jury instructions. Clearly, the deciding factor for the court in admitting the DNA-profile was that it enhances the prosecutors' ability to prove the identity of the suspect. ${ }^{56}$ The State v. Brown case goes in the same direction by deciding, that the DNA-evidence in regard to the profile as well as the population genetics was reliable and admissible. The central issue here was, what is the duty of the judge and what of the jury. The judge has only to determine, if the DNA-evidence is scientifically reliable and whether it will assist the jury in its deliberations. The result reliability has to be determined by the jury. ${ }^{57}$

In summing up, the relevancy-standard comes quite close to the requirements of the strict Frye interpretation. Although, I think here the legal basis on which the admissibility is based on, is to a certain extent more transparent.

\subsubsection{The modified Frye-standard}

The modified Frye-standard was developed in the People v. Castro case that mirrors concerns about the technology and population genetics of DNA-profiling. Of special concern was the issue of confusing the jury. ${ }^{58}$ The court developed a three-step test with the following questions to be answered:

Is there a generally adopted theory underlying the DNAtechnology? Are there generally accepted techniques that are capable of producing reliable results? Did the testing laboratory use the accepted scientific techniques in analysing the DNA-sample in this particular case (result reliability)?

The first two questions were concluded in the usual Fryestandard manner, which means that the court approved the whole DNA-technique as generally accepted in the scientific community. The crucial point was the last question of result reliability. The judge decided that this question is also to be determined in the pre-trial hearing, thus excluding the jury. Two underlying arguments were given. Firstly, the jury is supposed to be unable to understand such complex scientific matters as to whether the laboratory performed the DNA-tests in the correct manner. Secondly, the concern that the jury will disproportionately give too much weight to the DNA-evidence. This tendency of striping the jury of its powers in deciding the result reliability has been substantiated in a series of judgements. The consequence is that the judge now determines the scientific and the result reliability which is in clear contradiction to the different tasks assigned to the judge and the jury. ${ }^{59}$ Thus, all mentioned variations of the Frye-standard revolve around the question of 'general acceptance' and 'result reliability'. In my opinion, this is a dangerous development because neither the judge nor the jury can evaluate DNAevidence without the help and guidance of an expert witness. This results in an uncontrollable reliance on experts.

\section{1. $\underline{\text { 4. Australia }}$}

From the beginning it should be remembered, that the current legislation in Australia does not specifically authorize the police of taking samples for DNA-tests. Presently, in two states a draft is discussed for regulating this matter. ${ }^{60}$ For an appropriate discussion we have to draw a distinction between obtaining DNA-samples with or without consent and before or after arrest/custody.

Without consent and before arrest no legal authorization to take a blood sample or other body material exists, otherwise such an obtaining would constitute a battery. Without consent but after arrest the police has three possibilities that may cover the collection of genetic material of the arrested person: (a) searching the detainee, (b) taking fingerprints or other particulars for the purpose of identification and (c) instituting the examination of the detainee by a registered medical practitioner.

(a) searching the detainee without consent

The search of a lawfully detained person extends to "anything found upon his/her body". That includes taking fingerprints even with force. However, case law suggests that it is very unlikely that a court would accept the obtaining of DNA-samples as being covered by this search-authorization. ${ }^{61}$

(b) taking particulars for identification without consent

In all states of Australia the police enjoys the power to take particulars of the detainee for the purpose of identifying $\mathrm{him} / \mathrm{her}$. The extent varies in the various states. For example, in Victoria the extend is limited of taking only fingerprints. Whereas in most other states the possibilities go as far as taking photographs, dental impressions, voice 
recordings or handwriting samples. In Western Australia, NSW and Queensland for instance, this authority is only described in general terms:

"[...] all such particulars as may be deemed necessary for the identification of such a person."

As examples photographs, fingerprints, palm-prints are cited. The question is, whether also the taking of DNAsamples for the purpose of identification is covered as well. The courts have given the police a wide discretion of what methods are to be used. In the McPhail case the judge held:

"[...] that this gives an officer a very wide discretion as to when particulars of identification can be required ... Recently, blood, hair and semen samples have become a feature of identification [...]". ${ }^{2}$

In my mind, this case makes it obvious that also the taking of blood, hair or semen samples for conducting DNAprofiling is covered by this power and thus can be ordered by the police without the consent of the detainee.

(c) instituting an examination of the detainee by a registered doctor

Finally, the police can institute a medical examination of the arrested person. The question arises what kind of medical examination is meant. Consistent case law shows, that taking blood samples for standard blood tests is clearly covered by this authorization. Another issue is whether the subsequent DNAprofiling is included or not. Newly introduced legislation expressly authorizes the taking of blood, semen or hair samples during the medical examination, implying that DNA-profiling could be included as well. However, it should also be mentioned that the police in Australia has quite similar procedural limits like in England. Here also reasonable grounds are required: the order must be given by police officer of a certain rank or even by a magistrate, the detainee has to be informed and the sample must be taken by registered doctor. ${ }^{63}$

Evidently the current legal basis for conducting the DNA-profile with lawfully obtained samples is still murky. As it seems now, the police has the power to obtain blood samples and to order that a DNA-profile is to be done. In regard to admissibility of scientific evidence, the court and the jury have to rely heavily on the 'guidance' of an expert witness throughout the trial. The expert witnessguidance - as I would call it - consists of two interrelated parts of his/her testimony, one part is testifying upon the facts of the DNA-profiling and the other part is the expert witness' opinion in regard to the conclusions which ought to be drawn from the DNA-test. Normally, the part concerning the testimony of facts is without problems and is admissible without further discussion. The expert will testify upon how the DNA-test was performed, about occurred problems, the methods used etc. Totally opposite is the situation concerning the testimony of opinion. Generally, the expert witness testimony is restricted to questions relating to the facts. However, in cases of scientific evidence the judge and the jury are usually not sufficiently qualified as to draw the appropriate conclusions of such complex evidence. Hence, the expert witness opinion may be admissible under the following circumstances:

a. jury unfamiliarity with the scientific evidence,

b. existence of a relevant field of expertise in the interpretation of that material and expert witness must be sufficiently qualified on the subject. ${ }^{64}$

(a) jury unfamiliarity with the scientific evidence

Principally, the admissibility of expert opinion is only possible in cases, in which the jury needs the help of the expert to draw its inferences. This principle has been restated very often. In the recent Murphy v R. case it was stated again that:

"[...] any rule of excluding opinion evidence is limited to cases where, in the judgement of the court, it will not help the jury. [...]" 65

It is more than obvious, that barely any jury or any judge could evaluate the audiorodiographs which merely show the DNAstrands without any sort of guidance of an expert. However, as I explained in the first part, it is indispensable to understand the methods of calculating the population genetics in order to evaluate the convincing power of DNA-evidence in a particular case. Thus, in all cases expert witness opinion will come into play - in one way or another.

(b) existence of a relevant field of expertise in the interpretation of DNA-tests

This question is solved in Australia by applying the US Fryestandard. As important examples the R v. Elliot and the Gilmore $^{66}$ case illustrate the Frye-standard used. The court held that DNAprofiling is generally accepted as well as 
the underlying methods, thus DNA-evidence was admitted. For details I refer to section above that deals with the US Frye-standard.

(c) experts sufficient qualifications

The judge has great difficulties to determine the qualification of the expert. How can he be competent to evaluate whether the expert witness has the sufficient qualifications in such a new area of science. Furthermore, other aspects have to be considered, for example, the impartiality of the expert witness as well as the proper conduct of the DNAtests. These difficulties are reflected in several cases where courts have adopted a more cautious approach to this complex scientific evidence. Nevertheless, it is clear that the courts are willing to admit DNA-evidence in spite of all the potential errors and doubts. They want to leave it all to an unqualified jury which in turn depends fully on the opinion of the expert witness.

This lengthy examination of the legal situation in Germany, England, United States and Australia illustrates, that the legal basis of the entire DNA-issue is more than wobbly. Presently, no clear legislation is at hand. Instead, courts are stretching the current laws to an improper limit as well as using excessive interpretations in order to squeeze the DNAissue in the present case-law and legislation. Not enough with that, many courts also disregard possible dangers and errors and do not see possible misuse of DNA-technology. In my view, this is a very dangerous and unacceptable situation that has the potential to cause much unjust.

\section{DNA-PROFILING AND INFORMATION TECHNOLOGY FOR CRIME PREVENTION AND DETECTION}

In the previous section, I reflected on the DNA-issue primarily on a legal level. However, to com- prehend the full impact of DNA-profiling, we have to turn our attention to a more global level. At this level we have to understand DNA-profiling in the light of an additional weapon in the arsenal of the police in their daily fight against crime. We should not - as many lawyers and scholars do - overlook the fact that DNA-profiling is not exclusively a sort of a 'state', 'public' or 'police' subject matter but rather has grown to a matter that involves private (organizations) interests' as well.

For instance, private and state owned insurance companies have an eminent interest in knowing whether their clients have genetic distortions or predispositions, that may indicate possible future health problems. Furthermore, insurance companies quickly embrace any scientific claim that offers genetic predispositions as a tool of calculating life expectancy, thus enabling them to improve their risk calculations or even to deny individuals an insurance, which they otherwise would not have turned down. ${ }^{67}$ In addition, all companies of all sectors are eager to foresee possible (dis)or advantages of certain genetic predispositions of their workers and employees. ${ }^{68}$ For example, chemical and military companies have examined DNA of its workers in order to detect whether certain workers are more susceptible or more resistant to certain chemicals used at the working place. ${ }^{69}$ Besides, companies that offer and perform DNA-tests are eager to collect as many as possible DNA-data to update their population genetics data. Finally, private detective companies might be increasingly interested in utilising DNA-technology and DNAdata for their own investigations. These examples clearly indicate that the DNA-issue has crossed the border of being exclusively a police matter.

\subsection{General framework of prevention}

Before entering into the discussion of current crime prevention, I would like to explain my two main underlying observations in regard of the development of prevention in general and crime prevention in particular, on which this discussion is based on.

(a) extended intervention and increased personal data collection of the state

It has been widely observed, that the role of the state has faced tremendous changes in the past century. Increasingly, the state has to perform more and more tasks in innumerable fields i.e. social policy, environmental policy, technology policy, education, culture, fighting against organized crime, terrorism, drug-related crimes etc. The main reason for this, is the fast scientific-technological progress that forces the state to organize and take care of far more issues than it used to do. ${ }^{70}$

This - still ongoing development - has two effects. Firstly, it emphazises the concept of prevention and secondly, prevention requires inevitably an increased collection of personal information of all sorts. ${ }^{71}$ It is obvious, because of the extended involvement of the state, it tries to focus on prevention as much as possible, in order to bring the number of issues that seriously have to be dealt with down. The more problems, troubles and costs can be avoided in advance, the easier and cheaper it is to tackle the matters which become real problems. Furthermore, the more 
personal data are available, the faster can the trouble spots be located and eliminated. Thus, we can detect an "expansion and reorientation of preventive government activities." 72

(b) crime prevention and detection by the police

In the past years we can detect an expanding tendency also in criminal law towards the "use of prevention to resolve systemic conflicts."73 This trend is based on a more fundamental change in the premises under which criminal law functions. We are moving from a "repressively constraining to a preventively planning model." ${ }^{74}$ This shift is actively supported by the German police agencies. Since the mid-70s the police started to campaign for an expansion of the grounds and the advance of the timing for police intervention. For implementing the new preventive approach, it was argued, that a fundamental modernization of the police - especially in regard to the utilization of new (computer) technologies were needed. ${ }^{75}$ In addition, the strong focus on specific crimes i.e. organized crimes, drug-related crimes or terrorism were helpful justifications to pursue an immense accumulation of personal data as well as introducing new information technology. ${ }^{76}$ Logically, the mere storing of data has not much benefit for prevention. It is the utilization, the comparison and the exchange of data facilitated by the computer that is the key for the new strategy.

The motto is: an 'offensive against crime' requires an 'offensive and systematic' data collection. ${ }^{77}$

This has been actively supported by new laws that allow an across the country data exchange without needing any concrete suspicion. This new 'operative criminological strategy' makes the computer the central instrument for obtaining a "big picture of the internal security" of the country. ${ }^{78}$ The begin was marked by the establishment of the INPOL-computer-connecting system of the German police in the early 80s, that allowed nation-wide exchange of data between all police stations. ${ }^{79}$ Furthermore, this is not restricted to the national level. On the contrary, the increasing co-operation within Europe as well as in the world has demonstrated an increasing exchange of personal information across the borders. ${ }^{80}$ Examples for this development are: Interpol, TREVI (of the European Community), ${ }^{81}$ the NEBEDEACPOL ${ }^{82}$ the planned Europol (Maastricht Treaty, Art. K.1), the Schengen Information System (under the Schengen Convention, Title IV). ${ }^{83}$

\subsection{DNA-data and information technology in crime prevention and detection}

First, we should draw a distinction between the forms in which the DNA-data is available. DNA-data can be in the form of a hair, blood, semen, saliva or urine sample. Then, it can be in the form of audioradiographs that show the DNA-bands, thus not needing the sample anymore. Finally, the audioradioghraphs (that look like bar codes) can be scanned into a computer and then digitalized, so as to convert them into bits and bytes for the use within computer networks. The first two types are not much of interest for the police, because they have not produced any useful results yet, whereas the digitalized DNAdata can be instantly processed within a network - just like any other data information.

The first question we have to look into is, whether a qualitative difference between DNA-data and ordinary personal data i.e. Name, date of birth, address, marital status, occupation etc. is made or not. As it seems now, the current practice of the police as well as proposed legislation do not suggest to treat DNA-data different from normal information. Current as well as proposed legis- lation either is completely silent as to what type of information is meant (presuming all types of information) or only speak about personal information in general without further elaboration. Thus, we can safely assume, that DNA-data is treated as comparable to ordinary personal data. For example, the BKA (Bundeskriminalamt) centrally stores fingerprints, x-ray films, results of blood and semen examinations $^{84}$ - so why should it not include DNA-profiles as well?

This is a very important conclusion, since it assumes that DNAdata can be processed in all the ways and with all the means as ordinary data. Hence, it allows me to use current laws as an example of what can be done with ordinary as well as DNA-data. As an example I will take the "Hessisches Gesetz über die öffentliche Sicherheit und Ordnung" (HSOG) of Jan. 1st, 1991. That is the new police law of the state of Hessen in Germany. All states of Germany have around the same time introduced new police laws that are quite similar, thus the example of Hessen can be seen as a mirror of the situation in entire Germany. In the following section, I will depict a few paragraphs out of the HSOG to demonstrate the incredible extent of the (legal) possibilities the police has in regard for data collection, storing and exchanging.

$\S 13$ (2) is the basis that allows the collection of personal data - what type of data is not said, thus can include DNAdata - even before the persons have acted. Here we find the preventive element ("zur Verhütung") that opens the door for unlimited collection of personal data of persons who, at that moment, have not acted against the law. $\S 20$ makes it more than clear that the collection of data is focused on the prevention of future crimes. Furthermore, data received without request by third parties can also be used. The question is, who or what is a third party? Can it be a 
DNA-laboratory that automatically transfers its data to the police? Are private detective firms meant, which give information to the police to initiate or direct investigations towards certain persons? Or companies that have conducted secretly their own DNA-tests of their employees, thus could provide these data? It seems that "Dritte" or third parties can be everything, including my examples. In § 22 (3) we find the international co-operation element, that enables data exchange across the borders and world-wide to amplify the concept of offensive crime prevention.

In summing up, it is evident that digitalized DNA-data of persons collected for crime prevention and detection purposes are almost boundless possible and definitely beyond individual's control. This is extremely appalling, because as it must be clear to everybody that DNA-data is not at all comparable to ordinary personal data. In contrast, the Ministry of Justice sees no problems for setting-up a DNA-data bank since it can be a necessary tool with which the police can fulfil its task effectively. ${ }^{85}$ Even more advanced and distressing are the developments in the United States as the following section will indicate.

\subsection{Trends in the United States}

The FBI asserts that "a national co-ordination effort is essential if the full law enforcement potential of DNAtechnology is to be realized." ${ }^{86}$ As a model for a DNA-data bank serves the Automated Fingerprint Identification System (AFIS) which stores millions of standard fingerprints of around the world. The AFIS digitalizes the fingerprints into a binary code for the computer's search algorithm. The DNA-data bank would operate in the same manner, however it is clear that the DNAdata bank search can provide a new quality of evidence. ${ }^{87}$

The legal step for setting-up a DNA-data bank has been taken in California, Colorado and King County (Washington). In this states legislation requires that sex offenders have to give blood and saliva samples for DNAprofiling as a condition for parole. This has been justified by the high recidivism rate (25\% are repeated offenders) of sex offenders ${ }^{88}$ However, this is not the end of the road yet. The introduction of DNAprofiling in England in 1987 was done by "voluntary" mass examinations of more than 500 individuals. This trend was followed in Germany where also a "voluntary" mass examination was conducted. ${ }^{89}$ A very horrifying example happened in 1987 in a small town in Pennsylvania, where only black men were requested to undergo the DNA-tests. ${ }^{90}$ Unquestionably, the request for a "voluntary" mass DNA-test can be a very powerful tool to pressure people to comply with giving DNA-samples. ${ }^{91}$ It could also be misused to concentrate on minorities and other target groups, which could reinforce the rise in xenophobia, nationalism and fascism.

\section{Conclusion and outlook}

This article tried to examine the question whether DNAprofiling in alliance with information technology can be a new wonder weapon for crime prevention and detection. The answer must be clearly given in the affirmative.

Definitely, DNA-profiling can yield results with a very high probability. However, countless problems, doubts, questions and risks are (in) directly linked to it. I have mentioned only a few and many more could be added.

Looking into the future, I would like to mention the newly developed PCR (Polymerase Chain Reaction) technology for obtaining a DNA-profile. The PCR is a multi-million fold replication of small amounts of available DNA, that makes it possible to conduct a DNA-profile with "virtually any amount of DNA."92 The PCR is not fully developed yet as a standard method, but in a few years it will substitute the current RFLP method. This will expand drastically the cases in which DNA-profiling can be conducted, which in turn will cause a more frequent use of it, that will bring the costs down, thus making DNAprofiling convenient for an increasing number of cases. In addition, a rapid integration of computer technology in the DNAprofiling procedure, especially in regard of analyzing and interpreting the DNA-strands, probably will lead to more trustworthy results, with the effect that lawyers and judges will more readily accept and rely on DNA-profiling.

Secondly, the continuous improvement of computer technology will cause a boost in personal data storing, comparing, processing and exchanging. This will increasingly take place on a European as well as world-wide level. In addition, private organizations and their interests will be more and more involved. This is so, because private companies offer and conduct DNA-profiling, thus are directly involved with the police investigation. Furthermore, insurance, chemical, military, nuclear and other companies are extremely interested in making use of results obtained by DNA-tests. The difficulty with private organizations is, that it is not possible to control their activities whereas in governments' agencies preventive steps could be taken more easily. ${ }^{93}$ 
Finally, the question is what about the individual human being. Evidently, the individual has no control of what is used for DNAfor such purposes. Of course, there are many laws that should prevent or control such matters. However, who can guarantee either based on existing laws and practices or on proposed legislation and anticipated practices. Thus, these are not - nightmares. I am seriously concerned that our right of privacy and protection of our ${ }^{94}$ The on

lawmakers understand and subsequently accept that new effective laws - have to be

\section{NOTES}

1 W. Bär, 'Genetische Fingerabdrücke', Kriminalistik (1989) p. 313;

2 H. Kimmich/W. Spyra/W. Steinke, 'Das DNA-profiling in der kriminaltechnischen und der juristischen Diskuission', Neue Zeitschrift für Strafrecht (1990) p. 318;

3 C. Rademacher, Die Zulässigkeit genetischer Analysemethoden im Strafverfahren (Frankfurt am Main 1992) p. 4;

4 R v Pitchfork and Kelly case;

5 E.P. Solomon/P.W. Davis, Human Anatomy and Physiology (New York 1983) p. 730;

6 For detailed explanation see S. Easteal/Mcleod/K. Reed, DNA-profiling, Principals, Pitfalls, Potential (Chur, Paris, Philadelphia, Melbourne 1991) pp. 15-23;

7 C. Rademacher, 'Zur Frage der Zulässigkeit genetischer Untersuchungsmethoden im Strafverfahren', Strafverteidiger (1989) p. 548;

8 G. Tondorf, 'Neue kriminaltechnische Entwicklungen - eine Herausforderung für den Strafverteidiger', Strafverteidiger (1993) p. 46, regarding the codified and non-codified DNA parts;

9 C. Rademacher, loc.cit., p. 546;

10 Approximately $1 \mu \mathrm{g}$ of recovered DNA which is equivalent to $20 \mu \mathrm{l}$ of blood is needed to conduct a DNA profile. S. Easteal, loc.cit., p. 53;

11 S. Easteal, loc.cit., p. 51;

12 I.M. Flannery, 'Frye or Frye not: should the reliability of DNA-evidence be a question of weight or admissibility?', American Criminal Law Review (1992) p.167;

13 S. Easteal, loc.cit., p. 58;

14 S. Easteal, loc.cit., p. 59;

15 I.M. Flannery, loc.cit., p.168;

16 The companies who offer the DNA-profiling claim that a DNA match of two individuals is as unlikely as 1 in 30 billion. See J. Neufeld/N. Colman, 'When science takes the witness stand', Scientific American (1990) p. 22;

Another estimation is put at 1 in 780,000,000,000,000. See N. McLeod, 'English DNA evidence held inadmissible', Criminal Law Review (1991) p. 583;

17 P. Alldrige, 'Recognising novel scientific techniques: DNA as a test case', Criminal Law Review (1992) p. 689;

18 S. Easteal, loc.cit., pp. 67-68; 
19 S.J. Young, 'DNA evidence - beyond reasonable doubt?', Criminal Law Review (1991) p. 266, citing the Reading case;

20 S. Easteal, loc.cit., pp. 15-23;

21 S. Easteal, loc.cit., p. 71;

22 P. Alldrige, loc.cit., p. 690. The point raised here is especially amplified by the fact that two companies (Lifecodes and Cellmark Diagnostics) have established a world-wide oligopoly in providing DNA-profiling and related know-how;

23 R.M. White/J.J.D. Greenwood, 'DNA fingerprinting and the law', The Modern Law Review (1988) p. 147;

24 For a detailed analysis of future developments, see S. Easteal, loc.cit., Chapter 8;

25 I.M. Flannery, loc.cit., p. 168;

26 For details see S. Easteal., loc.cit., p. 184;

27 One example is given by N. McLeod, loc.cit., p. 589;

28 I.M. Flannery, loc.cit., pp. 170-171; S. Easteal, loc.cit., pp. 146-147;

29 C. Roxin, Strafverfahrensrecht (Munich 1991), p. 224;

30 This new right was recognized in the "Volkszählungs-Urteil" of the German Constitutional Court BVerfGE 65, pp. 1 of 1983;

31 D. Ruderisch, 'Rechtliche und rechtspolitische Fragen der Humangenetik', Zeitschrift für Rechtspolitik (1992) p. 263 ;

32 See decisions of the BGH from 21.8.1990, Neue Juristische Wochenschrift, NJW (1990) p. 2944, BGH from 3.7.1990, NJW (1990), p. 2328, LG Darmstadt, Stafverteidiger (1989) , p. 424), LG Berlin, NJW (1989) p. 787; 33 Neue Zeitschrift für Strafrecht (1992) p. 554, a revision of the BGH, 12.8.1992 of a decision of the LG Hannover;

34 The strongest objections has C. Rademacher, loc.cit.; See also C. Rademacher, 'Verhinderung der genetische Inquisition', Zeitschrift für Rechtspolitik (1990) pp. 380-384;

35 D. Oberlies, 'Genetischer Fingerabdruck und Opferrechte', Strafverteidiger (1990) pp. 469-475;

36 Quoted in J. Simon, 'Genomanalyse - Anwendungsmöglichkeiten und rechtlicher Regelungsbedarf,' Monatsschrift für Deutsches Recht (1991) p. 11;

37 For a skilled discussion of these issues see C. Rademacher, loc.cit.;

38 C. Rademacher, loc.cit., p. 380;

39 C. Walker, 'DNA-profiling and Police Powers', Criminal Law Review (1990) p. 481;

40 C. Walker, loc.cit., p. 482;

41 C. Walker, loc.cit., p. 482; 42 C. Walker, loc.cit., p. 483; 43 C. Walker, loc.cit., p. 490; 44 C. Walker, loc.cit., p. 486; 45 P. Alldrige, loc.cit., p. 692; 46 P. Alldrige, loc.cit., p. 696;

47 R v. Pitchfork and Kelly, R v. Melias;

48 R v. Brown;

49 I.M. Flannery, loc.cit., p. 173; 50 I.M. Flannery, loc.cit., p. 173;

51 J. Neufeld/Colmann, loc.cit., pp. 20-21; 52 I.M. Flannery, loc.cit., p. 175;

53 I.M. Flannery, loc.cit., p. 176; 54 I.M. Flannery, loc.cit., p. 178; 
55 Selected recent court decisons, American Journal of Law \& Medicine (1991) p. 183;

56 I.M. Flannery, loc.cit., p. 184;

57 I.M. Flannery, loc.cit., p. 179; 58 I.M. Flannery, loc.cit., p. 179;

59 I.M. Flannery, loc.cit., pp. 182-183; 60 S. Easteal, loc.cit., p. 27;

61 S. Easteal, loc.cit., pp. 30-31;

62 S. Easteal, loc.cit., pp. 32-33; 63 S. Easteal, loc.cit., p. 37;

64 S. Easteal, loc.cit., p. 106; 65 S. Easteal, loc.cit., p. 113;

66 S. Easteal, loc.cit., pp. 119-120;

67 See J. Simon, loc.cit., p. 8;

68 D. Ruderisch, loc.cit., p. 263; J. Simon, loc.cit., p. 8;

69 D. Ruderisch, p. 263; J. Simon, pp. 8-10;

70 D. Grimm, 'Constitutional observations on the subject of prevention', in P.A. Albrecht/O. Backes, eds., Crime prevention and intervention, (Berlin 1989), p. 18;

71 D. Grimm, loc.cit., p. 19. 72 D. Grimm, loc.cit., p. 20.

73 P.A. Albrecht, ed., 'Prevention as a problematic objective in the criminal justice system', in P.A. Albrecht/O. Backes, eds., Crime prevention and intervention, (Berlin 1989), p. 47;

74 P.A. Albrecht, loc.cit., p. 49;

75 P.A. Albrecht, loc.cit., p. 53;

76 D. Krauß, 'Sicherheitsstaat und Strafverteidigung', Strafverteidiger (1989) p. 318;

77 P.A. Albrecht, loc.cit., p. 54;

78 O. Backes, ed., 'Criminal Justice without legitimacy', in P.A. Albrecht/O. Backes, eds., Crime prevention and intervention, (Berlin 1989) p. 82;

79 G. Ringwald, 'Gegenpol zu INPOL?', Zeitschrift für Rechtspolitik (1988) p. 179;

80 J. Wolter, 'Freiheitlicher Strafprozeß, vorbeugende Straftatenbekämpfung und Verfassungsschutz',

Strafverteidiger (1989) p. 365; R. Ellger, 'Datenexport in Drittstaaten', Computer und Recht (1993) pp. 2-12;

81 C.J.C.F. Fijnaut, 'Police co-operation within western Europe', in F. Heidensohn/M. Farrel, eds., Crime in Europe (London 1991) pp.102-120;

82 C.J.C.F. Fijnaut, loc.cit;

83 J.P.H. Donner, 'Abolition of border controls' in Free movement of persons, ASSER (1993) pp. 1-25;

84 R. Keller, 'Die Genomanalyse im Strafverfahren', Neue Juristische Wochenschrift (1987) p. 2291, footnote 14;

85 C. Rademacher, loc.cit., p. 4;

86 A. de Gorgey, 'Implications for information privacy', American Journal of Law \& Medicine (1990) p. 383;

87 A. de Gorgey, loc.cit., p. 384; 
88 A. de Gorgey, loc.cit., p. 387; 89 C. Rademacher, loc.cit., pp. 2-3;

90 A. de Gorgey, loc.cit., p. 385, footnote 22; 91 R.M. White/J.J.D. Greenwood, loc.cit., p. 150; 92 S. Easteal, loc.cit., p. 129;

93 C. Kleis, 'Spiros Simitis - Der Datenschutzbeauftragte', Neue Kriminalpolitik (1992) p. 43;

94 My concerns are shared by C. Rademacher, loc.cit., p. 547;

95 A. de Gorgey, loc.cit., p. 398;

\section{Bibliography}

P.A. Albrecht, 'Prevention as a problematic objective in the criminal justice system', in P.A. Albrecht/O. Backes, eds., Crime prevention and intervention (Berlin 1989) pp. 47-72;

P. Alldrige, 'Recognising novel scientific techniques: DNA as a test case', Criminal Law Review (1992) pp. 687698 ;

O. Backes, 'Criminal Justice without legitimacy', in P.A. Albrecht/O. Backes, eds., Crime prevention and intervention, (Berlin 1989) pp. 73-99;

W. Bär, 'Genetische Fingerabdrücke', Kriminalistik, (1989) pp. 313-318;

J.P.H. Donner, 'Abolition of border controls' in T.M.C. ASSER Instituut 1993, Free movement of persons pp. 1-25;

S. Easteal/N. McLeod/K. Reed, DNA-profiling; Principles, Pitfalls and Potential, (Chur, Paris, Philadelphia, Melbourne 1991);

R. Ellger, 'Datenexport in Drittstaaten', Computer und Recht (1993) pp. 2-12;

C.J.C.F. Fijnaut, 'Police co-operation within western Europe' in F. Heidensohn/M. Farrel, eds., Crime in Europe (London 1991) pp.102-120;

I.M. Flannery, 'Frye or Frye not: should the reliability of DNAevidence be a question of weight or admissibility?', American Criminal Law Review, (1992) pp. 161-186;

A. de Gorgey, 'Implications for information privacy, American Journal of Law \& Medicine (1990) pp. 381-398;

D. Grimm, 'Constitutional observations on the subject of prevention' in P.A. Albrecht/O. Backes, eds., Crime prevention and intervention (Berlin 1989) pp. 1328;

R. Keller, 'Die Genomanalyse im Strafverfahren', Neue Juristische Wochenschrift (1987) pp. 2289-2296;

H. Kimmich/W. Spyra/W. Steinke, 'Das DNA-profiling in der kriminaltechnischen und der juristischen Diskussion', Neue Zeitschrift für Strafrecht (1990) pp. 318-323;

C. Kleis, 'Spiros Simitis - Der Datenschutzbeauftragte', Neue Kriminalpolitik (1992) pp. 42-44;

D. Krauß, 'Sicherheitsstaat und Strafverteidigung', Strafverteidiger (1989) pp. 315-325;

N. McLeod, 'English DNA-evidence held inadmissible', Criminal Law Review (1991) pp. 583-590;

J. Neufeld/N. Colman, 'When science takes the witness stand', Scientific American (1990) pp. 19-25;

D.Oberlies, 'Genetischer Fingerabdruck und Opferrechte', Strafverteidiger (1990) pp. 469-475;

C. Rademacher, Die Zulässigkeit genetischer Analysemethoden im Strafverfahren, (Frankfurt am Main 1992); 
C.Rademacher, 'Zur Frage der Zulässigkeit genetischer Untersuchungsmethoden im Strafverfahren', Strafverteidiger (1989) pp. 546-550;

C. Rademacher, 'Verhinderung der genetischen Inquisition', Zeitschrift für Rechtspolitik (1990) pp. 380-384;

G. Ringwald, 'Gegenpol zu INPOL?', Zeitschrift für Rechtspolitik (1988) pp. 179-183;

C. Roxin, Strafverfahrensrecht (Munich 1991);

D. Ruderisch, 'Rechtliche und rechtspolitische Fragen der Humangenetik', Zeitschrift für Rechtspolitik (1992) pp. 260-264;

J. Simon, 'Genomanalyse - Anwendungsmöglichkeiten und rechtlicher Regelungsbedarf', Monatsschrift für Deutsches Recht (1991) pp. 5-14;

E.P. Solomon/ P.W. Davis, Human Anatomy and Physiology 1983, (New York 1983);

G. Tondorf, 'Neue kriminaltechnische Entwicklungen - eine Herausforderung für den Strafverteidiger', Strafverteidiger (1993) pp. 39-47;

C. Walker, 'DNA-profiling and Police Powers', Criminal Law Review (1990) pp. 479-493;

R.M. White/J.J.D. Greenwood, 'DNA fingerprinting and the law', The Modern Law Review (1988) pp. 145-155;

J. Wolter, 'Freiheitlicher Strafprozeß, vorbeugende Straftatenbekämpfung und Verfassungsschutz - zugleich Besprechung des Entwurfs eines StVÄG 1988', Strafverteidiger (1989) pp. 358-371;

S.J. Young, 'DNA evidence - beyond reasonable doubt?', Criminal Law Review (1991) pp. 264-267; 